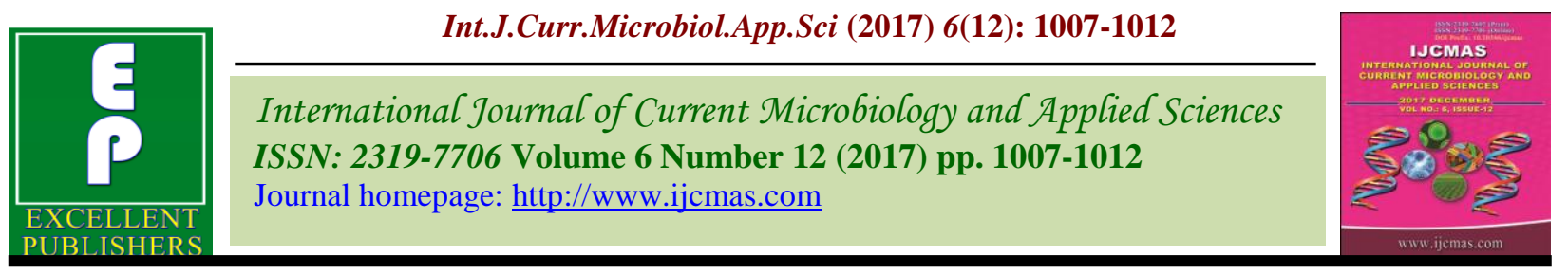

Original Research Article

https://doi.org/10.20546/ijcmas.2017.612.112

\title{
Correlation Studies for Fruit Yield and its Attributing Characters in Brinjal (Solanum melongena L.)
}

\author{
Praveenkumar Angadi*, K.M. Indiresh and A. Mohan Rao
}

College of Horticulture, Bengaluru, University of Horticultural Sciences, Bagalkot-587104, Karnataka, India

*Corresponding author

\author{
A B S T R A C T
}

\begin{tabular}{|l|}
\hline Ke y w o r d s \\
Brinjal, Yield, \\
Genotypic \\
correlation and \\
Phenotypic \\
correlation.
\end{tabular}

Keywords

\section{Introduction}

Brinjal (Solanum melongena L.) is one of the most popular and widely cultivated native vegetable crops of India. It is known as poor man's vegetable and also called as eggplant, garden egg and internationally aubergine.

It is grown mainly for its tender and immature fruits. They are primarily used as cooked vegetable in different parts of the world. It is also used for making pickles and dehydrated products. Eggplant is low in calories and has various macro and micro minerals which are beneficial for human health. Eggplant is also a rich source of potassium, magnesium, calcium and iron (Kowalski et al., 2003).
In India, it is one of the most common and popular vegetable crop grown throughout the country except higher altitudes. In India it is having a production of 135.60 lakh tonnes from an area of 7.11 lakh hectares and with a productivity of 19.10 tonnes per hectare. Orissa, Bihar, Karnataka, West Bengal, Andhra Pradesh, Maharashtra and Uttar Pradesh are the leading brinjal producing states. In Karnataka annual production of brinjal is 4.03 lakh tonnes from an area of 15.80 thousand hectares with productivity of 25.40 tonnes per hectare (Anon., 2015). Estimation of genetic parameters is needed to understand the genetic architecture of yield 
and yield contributing components. An evaluation of germplasm gives considerable data to classify the material. Germplasm collection, maintenance and its evaluation for economically important traits is a prerequisite for starting any breeding programme for the genetic improvement of the crop. But variability studies provide information on the extent of improvement possible in different characters but they do not throw light on the extent and nature of relationship existing between yield and various contributory characters.

As a rational approach for the improvement of the yield, selection has to be made for components of yield, since there may not be gene for yield per se but for various yield components. Further, many of these yield contributing characters are interacting in desirable and undesirable directions. Hence, the knowledge regarding the association of various characters among themselves and with economic characters is necessary for making indirect selection for improvement of economic traits. Character association or correlation is a measure of the degree of association between two characters. Keeping these aspects in view, the study has been taken up to analyse the correlation in brinjal (Solanum melongena L.) genotypes for seed content, fruit yield and its associated traits.

\section{Materials and Methods}

The experimental material consisting of nine genotypes were maintained in homozygous state at vegetable block, College of Horticulture, UHS campus, Bangalore.

The research station is located at $12^{0} 59^{\circ}$ North latitude and $77^{\circ} 35^{`}$ East longitude with an elevation of about $930 \mathrm{~m}$ above mean sea level (MSL) with sandy loam type of soil. The list of genotypes used in the study was presented in Table 1.
The seeds of these nine different genotypes were sown in the pro trays containing 98 holes during Kharif 2014. One month old seedlings were transplanted at spacing of 90 $\mathrm{cm}$ between rows and $60 \mathrm{~cm}$ between plants accommodating 20 plants per treatment per replication in a randomized block design with three replications. Five plants were selected and labelled at random from each replication in each treatment for recording the following observations and the average from these plants was worked out for the purpose of statistical computation (analysis). The observations were recorded for growth, fruit and seed parameters. The correlation coefficient among all possible character combinations at phenotypic $\left(r_{p}\right)$ and genotypic $\left(r_{g}\right)$ level were estimated employing formula by Al-Jibouri et al., 1958.

\section{Results and Discussion}

The genotypic and phenotypic correlation coefficient were worked out by utilizing data from nine genotypes of brinjal, sown in three replications and studied over 18 fruit yield and its contributing traits are presented in Table 2 and 3 respectively.

Genotypic correlation coefficients among growth and yield attributes are presented in Table 2. Fruit yield per plant showed positive and significant correlation with plant height (0.700), number of fruits per plant (0.653), fruit length (0.522), per cent fruit set (0.480), 100 seed weight (0.423), number of fruits per cluster (0.406) and average fruit weight (0.387) whereas, significant negative correlation was observed for days to 50 per cent flowering (-0.591), days to first flowering (-0.424) and pulp to seed ratio (0.378 ) at genotypic level (Table 2).

Phenotypic correlation coefficients among growth and yield attributes are presented in Table 3. Fruit yield per plant showed positive 
and significant correlation with number of fruits per plant (0.595), plant height (0.524), fruit length (0.499), number of fruits per cluster (0.390), average fruit weight (0.383), 100 seed weight (0.379) and per cent fruit set (0.382) whereas, negative and significant correlation was observed for days to first flowering (-0.391) at phenotypic level.

The phenotypic correlation indicates the extent of the observed relationship between two characters. This does not give true genetic picture of the relationship because it includes hereditary as well as environmental influences. Genotypic correlation provides an estimate of inherent association between genes controlling any two characters. Hence, it is of greater significance and could be effectively utilized in formulating an effective selection scheme. Therefore in the present study, the genotypic and phenotypic correlation coefficients were worked out for brinjal fruit yield and its components.

A narrow difference between the genotypic and phenotypic correlation coefficients was observed for various traits in the present finding and this indicates the lesser influence of the environment in the expression of these traits and presence of strong inherent association among the traits.

Correlation studies on fruit yield per plant and its component traits revealed that the values of genotypic correlation coefficient (Table 2) were higher than phenotypic correlation coefficient (Table 3). This may be due to effect of environment which modifying the total expression of the genotypes, thus altering the phenotypic expression. This suggests the strong inherent association among the traits. The fruit yield per plant exhibited highly significant and positive correlation with plant height, number of fruits per plant, fruit length, percent fruit set, hundred seed weight, number of fruits per cluster and average fruit weight at both genotypic and phenotypic levels. All these traits with highly significant positive association with fruit yield per plant also had high estimates of heritability. Thus, it can be concluded that simultaneous selection for these characters would be rewarding in improving the fruit yield in brinjal.

Table.1 List of brinjal genotypes included in the study

\begin{tabular}{|c|l|l|}
\hline Sl. No. & Germplasm & \multicolumn{1}{|c|}{ Source } \\
\hline 1 & Arka Shirish & IIHR, Bangalore \\
\hline 2 & Arka Anand & IIHR, Bangalore \\
\hline 3 & Haritha & KAU, Vellanikkara \\
\hline 4 & Swetha & KAU, Vellanikkara \\
\hline 5 & IIHR-3 & IIHR, Bangalore \\
\hline 6 & Mattigulla & COH, Bengaluru \\
\hline 7 & L-2863 & COH, Bengaluru \\
\hline 8 & Kuduchi local & COH, Arabavi \\
\hline 9 & Erangere local & COH, Mysore \\
\hline
\end{tabular}


Int.J.Curr.Microbiol.App.Sci (2017) 6(12): 1007-1012

Table.2 Estimates of genotypic correlation coefficients for growth, yield and seed parameters among nine parents of brinjal

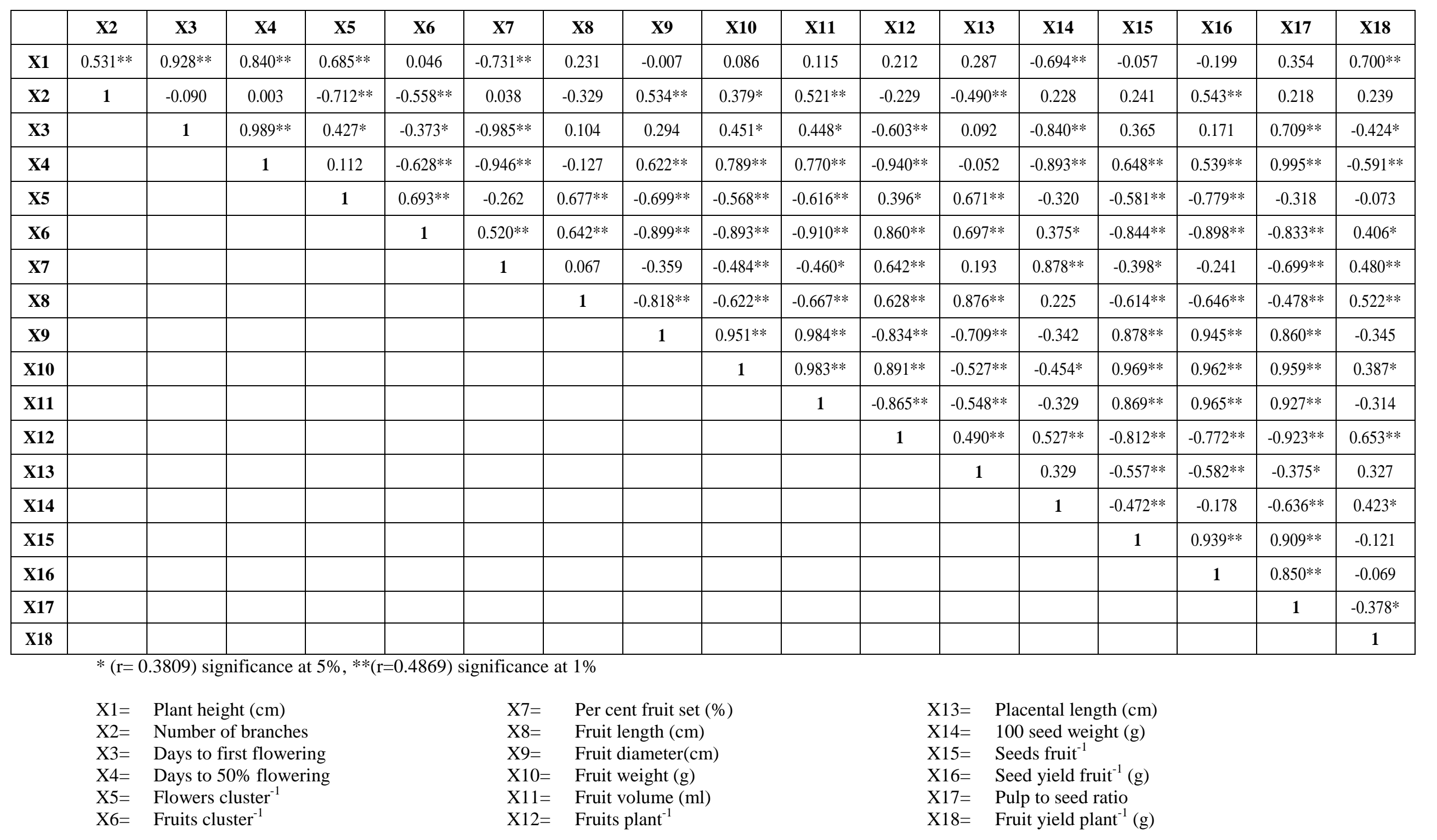


Table.3 Estimates of phenotypic correlation coefficients for growth, yield and seed parameters among nine parents of brinjal

\begin{tabular}{|c|c|c|c|c|c|c|c|c|c|c|c|c|c|c|c|c|c|}
\hline & $\mathrm{X} 2$ & $\mathbf{X 3}$ & X4 & X5 & X6 & X7 & X8 & X9 & X10 & X11 & X12 & X13 & X14 & X15 & X16 & X17 & X18 \\
\hline X1 & $0.471^{*}$ & $0.751 * *$ & $0.539 * *$ & $0.632 * *$ & 0.068 & $-0.625 * *$ & 0.256 & 0.001 & 0.100 & 0.108 & 0.195 & 0.297 & $-0.577 * *$ & -0.051 & -0.166 & 0.351 & $0.524 * *$ \\
\hline $\mathrm{X} 2$ & 1 & -0.108 & 0.058 & $-0.652 * *$ & $-0.517 * *$ & 0.059 & -0.296 & $0.508^{* *}$ & 0.327 & $0.477 *$ & -0.208 & $-0.458^{*}$ & 0.218 & 0.215 & $0.499 * *$ & 0.154 & 0.101 \\
\hline $\mathbf{X 3}$ & & 1 & $0.678^{* *}$ & 0.316 & -0.354 & $-0.761 * *$ & 0.039 & 0.227 & $0.411^{*}$ & 0.318 & $-0.501 * *$ & 0.062 & -0.666 & 0.242 & 0.155 & $0.620 * *$ & $-0.391 *$ \\
\hline X4 & & & 1 & 0.144 & $-0.517 * *$ & $-0.740 * *$ & -0.156 & $0.447 *$ & $0.5898 * *$ & $0.552 * *$ & $-0.609 * *$ & -0.046 & $-0.415^{*}$ & $0.468 *$ & $0.375^{*}$ & $0.728 * *$ & -0.327 \\
\hline X5 & & & & 1 & $0.636^{* *}$ & -0.305 & $0.649^{* *}$ & $-0.652 * *$ & $-0.529 * *$ & $-0.567 * *$ & 0.357 & $0.627 * *$ & -0.274 & $-0.535^{* *}$ & $-0.738 * *$ & -0.261 & -0.033 \\
\hline X6 & & & & & 1 & $0.519 * *$ & $0.618^{* *}$ & $-0.850 * *$ & $-0.861 * *$ & $-0.834 * *$ & $0.804 * *$ & $0.659 * *$ & 0.263 & -0.771 & $-0.843 * *$ & $-0.776^{* *}$ & $0.390 *$ \\
\hline $\mathbf{X 7}$ & & & & & & 1 & 0.044 & -0.329 & $-0.462 *$ & $-0.389 *$ & $0.559 * *$ & 0.169 & $0.663 * *$ & -0.355 & -0.228 & $-0.631 * *$ & $0.382 *$ \\
\hline X8 & & & & & & & 1 & $-0.749 * *$ & $-0.590 * *$ & $-0.616^{* *}$ & $0.574 * *$ & $0.830 * *$ & 0.206 & $-0.565 * *$ & $-0.576^{* *}$ & $-0.451^{*}$ & $0.499 * *$ \\
\hline X9 & & & & & & & & 1 & $0.926^{* *}$ & $0.951 * *$ & $-0.815^{* *}$ & $-0.689 * *$ & -0.292 & $0.853 * *$ & $0.907 * *$ & $0.807 * *$ & -0.302 \\
\hline X10 & & & & & & & & & 1 & $0.943 * *$ & $0.862 * *$ & $-0.511 * *$ & -0.377 & $0.931 * *$ & $0.920 * *$ & $0.943 * *$ & $0.383^{*}$ \\
\hline X11 & & & & & & & & & & 1 & $-0.834 * *$ & $-0.520 * *$ & -0.300 & $0.861^{* *}$ & $0.888^{* *}$ & $0.875^{* *}$ & -0.260 \\
\hline X12 & & & & & & & & & & & 1 & $0.484 *$ & $0.424 *$ & $-0.778 * *$ & $-0.719 * *$ & $-0.879 * *$ & $0.595^{* *}$ \\
\hline X13 & & & & & & & & & & & & 1 & 0.293 & $-0.531 * *$ & $-0.533 * *$ & -0.357 & 0.330 \\
\hline X14 & & & & & & & & & & & & & 1 & $-0.415^{*}$ & -0.129 & $-0.530 * *$ & $0.379^{*}$ \\
\hline X15 & & & & & & & & & & & & & & 1 & $0.888 * *$ & $0.845^{* *}$ & -0.114 \\
\hline X16 & & & & & & & & & & & & & & & 1 & $0.749 * *$ & -0.041 \\
\hline X17 & & & & & & & & & & & & & & & & 1 & -0.298 \\
\hline X18 & & & & & & & & & & & & & & & & & 1 \\
\hline
\end{tabular}

$*(\mathrm{r}=0.3809)$ significance at $5 \%, * *(\mathrm{r}=0.4869)$ significance at $1 \%$

$\mathrm{X} 1=\quad$ Plant height $(\mathrm{cm})$

$\mathrm{X} 2=$ Number of branches

$\mathrm{X} 3=$ Days to first flowering

$\mathrm{X} 4=$ Days to $50 \%$ flowering

$\mathrm{X} 5=$ Flowers cluster $^{-1}$

X6 $=$ Fruits cluster ${ }^{-1}$
$\mathrm{X} 7=\quad$ Per cent fruit set $(\%)$

$\mathrm{X} 8=\quad$ Fruit length $(\mathrm{cm})$

$\mathrm{X} 9=\quad$ Fruit diameter $(\mathrm{cm})$

$\mathrm{X} 10=$ Fruit weight $(\mathrm{g})$

$\mathrm{X} 11=$ Fruit volume $(\mathrm{ml})$

$\mathrm{X} 12=$ Fruits plant $^{-1}$
$\mathrm{X} 13=\quad$ Placental length $(\mathrm{cm})$

$\mathrm{X} 14=100$ seed weight $(\mathrm{g})$

$\mathrm{X} 15=$ Seeds fruit $^{-1}$

$\mathrm{X} 16=\quad$ Seed yield fruit ${ }^{-1}(\mathrm{~g})$

$\mathrm{X} 17=\quad$ Pulp to seed ratio

$\mathrm{X} 18=$ Fruit yield plant $^{-1}(\mathrm{~g})$ 
Positive and significant association of plant height, number of fruits per plant, fruit length, percent fruit set, hundred seed weight, number of fruits per cluster and average fruit weight with fruit yield per plant is in consonance with the findings of Arunkumar (2013). Positive correlation of plant height with yield is in conformity with the findings of Ponnuswami and Irulappan (1994) and Dhaka and Soni (2014). Positive correlation of per cent fruit set, fruit length and number of fruits per cluster with yield is in conformity with the findings of Kafytullah et al., (2011).

In the present study negative and significant association of yield with days to 50 per cent flowering, days to first flowering, pulp to seed ratio was observed at genotypic level whereas days to first flowering also had negative correlation at phenotypic level. Similar results were realized by Varma (1995).

\section{References}

Al-Jibouri, H. A., Miller, P. A. and Robinson, H. V., 1958, Genotypic and environmental variance and covariances in an upland cotton cross of interspecific origin. Agron. J., 50: 633-
636.

Anonymous, 2015, Indian Horticulture Database, Ministry of Agric. Government of India, pp. 127-135.

Arunkumar, B., 2013, Inheritance of bacterial wilt disease resistance in brinjal (Solanum melongena L.). Ph.D. Thesis, Uni. Agric. Sci., Bengaluru (India).

Dhaka, S. K. and Soni, A. K., 2014, Genotypic and phenotypic correlation study in brinjal genotypes. Ann. Pl. Soil Res., 16(1): 53-56.

Kafytullah, Indiresh, K. M. and Santhosha, H. M., 2011, Genetic variability in brinjal (Solanum melongena L.). Environ. Eco., 29(3B): 1679-1688.

Kowalski, R., Kowalska, G. and Wiercinski, J., 2003, Chemical composition of fruits of three eggplant (Solanum melongena L.) cultivars. Flo. Hort., 15: 89-95.

Ponnuswami, V. and Irulappan, I., 1994, Correlation studies in eggplant (Solanum melongena). South Indian Hort., 42: 314-317.

Varma, S., 1995, Variability and heterosis in green fruited brinjal (Solanum melongena. L). M.Sc. Thesis, Kerala Agric. Univ., Thrissur (India).

\section{How to cite this article:}

Praveenkumar Angadi, K.M. Indiresh and Mohan Rao, A. 2017. Correlation Studies for Fruit Yield and its Attributing Characters in Brinjal (Solanum melongena L.). Int.J.Curr.Microbiol.App.Sci. 6(12): 1007-1012. doi: https://doi.org/10.20546/ijcmas.2017.612.112 